Those who participated in the work were: A. L. Bacharach and E. Lester Smith, Glaxo Laboratories, Ltd., Greenford; R. G. Booth, British Cod Liver Oil Producers (Hull), Ltd.; W. A. Broom, Messrs. Boots Pure Drug Co., Ltd., Nottingham; H. M. Bruce and K. H. Coward, Pharmaceutical Society, London; A. D. Emmett, R. A. Brown and M. Sturtevant, Messrs. Parke, Davis and Co., Detroit Laboratories (communicated by J. A. Freeman); E. M. Hume, Lister Institute, London; J. O. Irwin, London School of Hygiene and Tropical Medicine; S. K. Kon, National Institute for Research in Dairying, Shinfield ; T. Moore, Dunn Nutritional Laboratory, Cambridge; R. A. Morton and J. R. Edisbury, University, Liverpool ; S. W. F. Underhill, Messrs. The British Drug Houses, Ltd., London; H. Wilkinson, Messrs. Lever Bros., Ltd., Port Sunlight.

$$
\text { E. M. Hume }
$$

(Secretary, Vitamin A Sub-Committee of Accessory Food Factors Committee, appointed by the Lister Institute and Medical Research Council).

Lister Institute,

London, S.W.1.

Dec., 15.

1 Natore, 139, 467 (1937).

2 Med. Res. Council, Special Report Series No. 202 (1935)

\section{A Rapid Visual Test for Vitamin A Deficiency}

THE recovery of vision after blinding by a bright light depends, among other things, on a reformation of visual purple from vitamin $\mathrm{A}$ in the blood. Various instruments have been used to test this relationship, but have been severely criticized. In all such work, at least fifteen minutes have been needed for each test, and usually much longer.

A new apparatus has been devised to test vitamin A deficiency rapidly. After looking at a bright light of certain intensity for 30 seconds, the time needed to see a dim light of constant intensity is taken (in distinction to instruments which have complicated means for varying the intensity of the dim light). The range of recovery times is $3-50$ seconds, an average test takes less than a minute, and two or three tests are made within five minutes of the subject entering the room. Up to forty persons an hour have been tested.

Treatment with vitamin A of 123 people having more than fifteen seconds recovery time (taken as deficient), showed a response in all cases but three, ending in a recovery time of ten seconds or less (taken as normal). Thirty other cases treated with an A-free oil showed no change on repeated tests.

A normal person beginning at eight seconds placed on an A-deficient diet gradually lengthened in recovery time until a time of twenty-seven seconds was reached. At this point hæmeralopia, asialia and other symptoms of A-deficiency were present.

Normal recovery time on this apparatus is considered to be ten seconds or less, and over fifteen seconds is deficient. These somewhat arbitrary times were arrived at in the following way: (1) An early survey of a hundred people was plotted to show the number of cases at each recovery time. The form of this curve is the same with our present total of 1,200 cases. The mode is eight seconds, and there is a pronounced dip at 11 seconds. All values less than eleven seconds were therefore tentatively adopted as normal. (2) Large amounts of vitamin A have no effect on recovery times already at ten or less; but recovery times at twelve or twenty or more, treated with vitamin A come to values of ten or less, depending on the individual.

In a survey of a thousand university students, 52 per cent were normal (3-10 sec.), 24 per cent border-line (11-15 sec.), and 24 per cent deficient (16 or more) with respect to vitamin $A$.

From these students, 753 case histories were obtained, and the following are some of the relation. ships found :

\begin{tabular}{|l|c|c|c|}
\hline & $\begin{array}{c}\text { Normal } \\
\text { (per cent) }\end{array}$ & $\begin{array}{c}\text { Border-line } \\
\text { (per cent) }\end{array}$ & $\begin{array}{c}\text { Deficient } \\
\text { (per cent) }\end{array}$ \\
\hline $\begin{array}{l}\text { Cold within a month } \\
\text { after test }\end{array}$ & $54 \cdot 5$ & 64 & $71 \cdot 5$ \\
Night blindness & 7 & 18 & 19 \\
Dry skin & 7 & 16 & 18 \\
\hline
\end{tabular}

A total of 1,200 people have been tested and no relation has been found to sex, age, colour of eyes, wearing of glasses if usually worn, myopia, hypermetropia, astigmatism or fatigue. These and other factors are still being investigated. On the other hand, every deficient case has been found to have had a low intake of vitamin A (where calculated this has ranged from 500 to 2,000 I. U. daily).

Full details of the apparatus, and of these investigations, will be published elsewhere.

Department of Biochemistry,

L. B. Petr.

University of Alberta, Edmonton.

Nov. 25.

Laccase, a Blue Copper-Protein Oxidase from the Latex of Rhus succedanea

IN 1883 Yoshida $^{1}$ discovered, in the latex of the Japanese lacquer tree (Rhus vernicifera), a thermolabile substance which was responsible for the darkening and hardening of the lacquer.

To Bertrand ${ }^{2}$ we owe the first extensive study of this substance which he found in the latex of an Indo-Chinese lacquer tree (Rhus succedanea). $\mathrm{He}$ described this substance under the name of laccase, and showed it to be an enzyme capable of catalysing the oxidation of different polyphenols such as hydroquinone, pyrogallol and others. He has also shown that the darkening and hardening of latex is due to the catalytic oxidation by this oxidase of natural polyphenols, urushiol and laccol. This important discovery of Bertrand was confirmed and extended by other workers and more recently by Suminokura ${ }^{3}$ and Brooks 4

The laccase for our present study was obtained from the latex of Rhus succedanea. For the extraction and purification of the enzyme the latex is treated with acetone, the precipitate is dried, extracted with water and the enzyme is then purified by a method somewhat similar to that used by us for purification of polyphenol oxidase of mushrooms ${ }^{5}$.

The purified enzyme catalyses the oxidation of polyphenols and diamines, the oxidation of $p$-phenylenediamine being twice as fast as that of catechol. Monophenols such as $p$-cresol or tyrosine are not oxidized at all by purified laccase even when tested for ninety minutes. Both crude and partly purified enzymes catalyse the oxidation of asorbic acid without the addition of a carrier such as catechol.

The purest enzyme preparation obtained has a strong blue colour. It is devoid of hæmatin, iron and 